\title{
18. SEGREGATION VESICLES AND IMMISCIBLE LIQUID DROPLETS IN OCEAN-FLOOR BASALT OF HOLE 396B, IPOD/DSDP LEG 46
}

\author{
Hiroaki Sato, Department of Earth Sciences, Kanazawa University, Kanazawa, Ishikawa 920, Japan
}

\section{INTRODUCTION}

In the ocean-floor basalts of Leg 46, Hole 396B, mafic spherules similar to the segregation vesicles of Smith (1968) are common. Segregation vesicles are the vesicles infilled with the residue from the crystallizing magma surrounding them and may retain the composition of the residual melt at a certain period of the crystallization of groundmass. The author made electronprobe microanalyses of the segregation vesicles and the interstitial matrices to find the compositions of the residual liquids during the crystallization of groundmass.

Dark minute glass droplets set in a light-colored glass are found in the mesostasis of the most coarse-grained part of pillow and massive lavas of Hole 396B. The texture of the droplets is similar to those of the immiscible liquid droplets in lunar and terrestrial basalts (Roedder and Weiblen, 1970, 1971; De, 1974). The interstitial light-colored glasses in the mesostasis of the massive lava have compositions of trondhjemite or plagiogranite, and represent the last few per cent of the residue during fractional crystallization of the groundmass. In this report, I describe these groundmass materials to show the intra-lava fractionation behavior of Hole 396B basalts.

\section{SEGREGATION VESICLES AND INTERSTITIAL MATRIX}

Segregation vesicles occur in the microcrystalline and intersertal parts of pillows and massive lavas of Hole 396B, and are absent at the quenched pillow margin as well as at the intergranular interior of the massive lava of Core 15. The diameter of the segregation vesicles ranges from 0.05 to $1.0 \mathrm{~mm}$, and tends to be larger than the coexisting vesicles. The filling can be seen in various stages of completion from thin crescents lining the cavity to wholly filled vesicles (Plate 1, Figures 2 and 3). Segregation vesicles are composed mainly of dendritic clinopyroxene with minute interstitial crystals of plagioclase and titanomagnetite, and mesostasis (Plate 1, Figures 4 and 5). Segregation vesicles are commonly surrounded by tangential groundmass plagioclase laths in the intersertal part of pillow and massive lavas (Plate 1, Figure 1), though some of them are delineated by the oblique plagioclase laths in the microcrystalline parts of pillows (Plate 1, Figures 2 and 3 ). The constituents and the texture of the segregation vesicles are very similar to the polygonal intersticies of the surrounding groundmass (Plate 1, Figure 6). The grain size of the constituents of segregation vesicles increases simultaneously with that of the surrounding groundmass.
Chemical compositions of some of the segregation vesicles and the interstitial material of groundmass from the complete pillow interval of Section 20-1 are obtained by electronprobe (Table 1). The analyses were made by using an electron beam with a $10-\mu \mathrm{m}$ diameter, and 20 spot analyses on one segregation vesicle were averaged to represent one column of analyses in Table 1 . In the table, bulk rock as well as sideromelane glass compositions of the same pillow are shown. In comparison with the sideromelane glass, segregation vesicles are enriched in $\mathrm{TiO}_{2}$, total $\mathrm{Fe}$ as $\mathrm{FeO}^{*}, \mathrm{MnO}, \mathrm{CaO}$, and $\mathrm{K}_{2} \mathrm{O}$, and depleted in $\mathrm{Al}_{2} \mathrm{O}_{3}$ and $\mathrm{MgO}$. High $\mathrm{FeO} * / \mathrm{MgO}$ ratios of the segregation vesicles indicate that they are the residual melt during fractional crystallization of the groundmass. C.I.P.W. norm composition of the segregation vesicles is high in Ca-rich pyroxene component and low in plagioclase component compared with the glass. The chemistry of the polygonal

TABLE 1

Chemical Compositions of Fillings of Segregation Vesicles and Interstitial Tachylite in Groundmass in a Pillow of Section 396B-20-1

\begin{tabular}{|c|c|c|c|c|c|c|c|}
\hline $\begin{array}{l}\text { Piece Number } \\
\text { Interval }(\mathrm{cm})\end{array}$ & $\begin{array}{c}4 \mathrm{~B} \\
53-55\end{array}$ & $\begin{array}{c}4 \mathrm{~F} \\
83-84\end{array}$ & $\begin{array}{c}41 \\
113-122\end{array}$ & & $\begin{array}{c}4 \mathrm{G} \\
93-102\end{array}$ & & \\
\hline & $\begin{array}{c}1 \\
\text { (bulk) }\end{array}$ & $\begin{array}{c}2 \\
\text { (glass) }\end{array}$ & $\begin{array}{c}3 \\
(\text { S.V. })^{\mathrm{a}}\end{array}$ & ${ }^{4}$ & $\begin{array}{c}5 \\
\text { (S.V.) }\end{array}$ & $\begin{array}{c}6 \\
\text { (S.V.) }\end{array}$ & $\begin{array}{c}7 \\
\text { (I.T.) }\end{array}$ \\
\hline $\mathrm{SiO}_{2}$ & 49.92 & 50.6 & 51.3 & 50.6 & 52.6 & 49.1 & 51.9 \\
\hline $\mathrm{TiO}_{2}$ & 1.04 & 1.35 & 2.36 & 2.79 & 2.69 & 2.37 & 2.78 \\
\hline $\mathrm{Al}_{2} \mathrm{O}_{3}$ & 17.64 & 15.3 & 11.68 & 10.10 & 11.10 & 10.28 & 9.98 \\
\hline $\mathrm{Fe} 0$ & 7.93 & 9.39 & 11.57 & 12.33 & 12.59 & 11.94 & 12.58 \\
\hline Mn0 & 0.16 & 0.16 & 0.23 & 0.28 & 0.22 & 0.27 & 0.26 \\
\hline $\mathrm{Mg} 0$ & 7.39 & 7.89 & 5.76 & 4,75 & 6.71 & 6.99 & 5.91 \\
\hline $\mathrm{CaO}$ & 12.79 & 14.11 & 14.11 & 13.89 & 13.58 & 14.57 & 12.29 \\
\hline $\mathrm{Na}_{2} \mathrm{O}$ & 2.42 & 2.75 & 2.75 & 2.41 & 2.73 & 2.72 & 2.56 \\
\hline $\mathrm{K}_{2} \mathrm{O}$ & 0.21 & 0.25 & 0.25 & 0.28 & 0.38 & 0.38 & 0.45 \\
\hline $\mathrm{P}_{2} \mathrm{O}_{5}$ & 0.11 & & & & & & \\
\hline $\mathrm{H}_{2} \mathrm{O}(+)$ & 0.88 & & & & & & \\
\hline Total & 100.49 & 99.1 & 100.0 & 97.4 & 102.6 & 98.9 & 98.7 \\
\hline$q z$ & & & & 3.3 & & & 3.2 \\
\hline or & 1.12 & 0.6 & 1.5 & 1.7 & 2.2 & 2.3 & 2.7 \\
\hline$a b$ & 20.5 & 23.8 & 23.2 & 20.9 & 22.5 & 23.2 & 21.9 \\
\hline an & 36.8 & 29.3 & 18.8 & 16.3 & 16.5 & 14.9 & 14.6 \\
\hline wo & 10.9 & 11.8 & 21.4 & 22.7 & 20.5 & 24.3 & 19.7 \\
\hline en & 12.8 & 15.0 & 14.2 & 12.1 & 16.2 & 9.2 & 14.9 \\
\hline fs & 7.7 & 9.7 & 14.5 & 15.5 & 15.1 & 7.8 & 15.7 \\
\hline fo & 3.9 & 3.4 & 0.1 & & 0.1 & 5.9 & \\
\hline fa & 2.6 & 2.4 & 0.1 & & 0.1 & 5.5 & \\
\hline$m t^{c}$ & 1.3 & 1.5 & 1.9 & 2.0 & 2.0 & 1.9 & 2.1 \\
\hline il & 2.0 & 2.6 & 4.5 & 5.4 & 5.0 & 5.1 & 5.3 \\
\hline ap & 0.3 & & & & & & \\
\hline
\end{tabular}


intersticies of the groundmass has similar features, but it is slightly higher in $\mathrm{FeO}^{*} / \mathrm{MgO}$ ratio than the segregation vesicles.

\section{Liquid Immiscible Droplet (Plate 2)}

Minute high-index glass droplets set in a low-index glass occur within the mesostasis of well-crystallized pillow and massive lavas. The texture of the droplets is similar to those of the immiscible liquid droplets in lunar basalts (Roedder and Weiblen, 1970) and in experimental products (Watson, 1976; Irvine, 1977); and is thought to have a similar origin. The size of the droplets is 1 to $4 \mu \mathrm{m}$ in the massive lava of Core 15 , and 1 to $2 \mu \mathrm{m}$ in pillow lavas. According to Roedder and Weiblen (1970), liquid immiscible droplets in lunar basalts are classified as high- and low-index glasses. In the case of Leg 46 basalts, only the high-index type of droplet was observed, as is the case for other terrestrial basalts (De, 1974; Roedder and Weiblen, 1972). Most of the mesostasis in the intergranular part of massive lava is charged with high-index droplets, while there is mesostasis mostly composed of low-index glass. Mesostasis constitutes 2 to 5 per cent of the rock, and is surrounded by groundmass consisting of olivine, plagioclase, Ca-rich clinopyroxene, titanomagnetite, sulfide, and/or ilmenite. Chemical composition of the low-index glass that is almost free from the high-index glass droplets is shown in Table 2. The low-index glass is enriched in silica and sodium, and is similar to the immiscible low-index glass of the experimental products of Massion and Koster von Groos (1973). The composition of this low-index glass nearly coincides with that of the plagiogranite of Coleman and Peterman (1975).

\section{DISCUSSION}

Segregation vesicles in Leg 46 basalts are similar to those in the Australian pillow lavas (Smith, 1968) and in Leg 37 basalts (Barager et al., 1976). The common features between the fillings of the segregation vesicles and the intersticies of the surrounding groundmass observed in Leg 46 basalt confirm the argument of Smith that the fillings represent the residual melt infiltrated into vesicles at a certain period during the crystallization of groundmass. That the $\mathrm{FeO} / \mathrm{MgO}$ ratio of the fillings is lower than that of the interstitial material of the groundmass indicates the fillings retained earlier composition of the changing residual melt. The composition of the fillings of segregation vesicles and interstitial material can be derived from the composition of the quenched glass by 40 to 60 per cent fractionation of olivine, plagioclase, and minor amounts of Ca-rich clinopyroxene, which is in harmony with the petrographic observation that interstitial material in the intersertal groundmass composes about half of the bulk groundmass.

On the other hand, compositional variation of the residual melt during groundmass crystallization, as represented by compositions of the fillings of segregation vesicles and the interstitial matrices of the groundmass, differs from the general fractionation trends of ocean-floor basalts (Miyashiro et al., 1969; Clague and Bunch, 1976). This is well illustrated in the ternary projections within the system silica-olivine-Ca pyroxene-plagioclase from the silica and plagioclase apices (Figure 1). In Figure 1, the composition of ocean-floor basalt changes toward silica apex as the
TABLE 2

Chemical Compositions of Mesostasis Glasses in a Massive Lava, Core 396B-15, IPOD/DSDP Leg 46

\begin{tabular}{|c|c|c|c|c|c|}
\hline $\begin{array}{c}\text { Section } \\
\text { Interval }(\mathrm{cm}) \\
\text { Piece }\end{array}$ & $\begin{array}{c}3 \\
15-24 \\
1\end{array}$ & $\begin{array}{c}4 \\
30-45 \\
2\end{array}$ & $\begin{array}{c}4 \\
30-45 \\
3\end{array}$ & $\begin{array}{c}4 \\
30-45 \\
4\end{array}$ & $\begin{array}{c}4 \\
112-124 \\
\text { Bulk Rock }\end{array}$ \\
\hline $\mathrm{SiO}_{2}$ & 63.03 & 68.36 & 70.03 & 73.60 & 48.94 \\
\hline $\mathrm{TiO}_{2}$ & 1.33 & 0.87 & 0.72 & 0.50 & 1.68 \\
\hline $\mathrm{Al}_{2} \mathrm{O}_{3}$ & 14.08 & 13.96 & 13.89 & 14.91 & 14.82 \\
\hline $\mathrm{FeO}$ & 5.57 & 6.26 & 3.32 & 2.61 & 9.88 \\
\hline $\mathrm{MnO}$ & 0.17 & 0.06 & 0.03 & 0.03 & 0.14 \\
\hline $\mathrm{MgO}$ & 1.53 & 0.85 & 2.28 & 0.37 & 7.44 \\
\hline $\mathrm{CaO}$ & 2.12 & 3.52 & 2.54 & 2.24 & 10.58 \\
\hline $\mathrm{Na}_{2} \mathrm{O}$ & 5.94 & $0.96^{\mathrm{a}}$ & $1.50^{\mathrm{a}}$ & 5.73 & 2.79 \\
\hline $\mathrm{K}_{2} \mathrm{O}$ & 0.28 & 0.36 & 0.47 & 0.46 & 0.18 \\
\hline $\mathrm{P}_{2} \mathrm{O}_{5}$ & & & & & 0.17 \\
\hline $\mathrm{H}_{2} \mathrm{O}(+)$ & & & & & 1.21 \\
\hline $\mathrm{H}_{2} \mathrm{O}(-)$ & & & & & 1.37 \\
\hline Total & 94.05 & 95.21 & 94.78 & 100.45 & 99.46 \\
\hline $\mathrm{qz}$ & 18.6 & 25.5 & 27.1 & 31.5 & \\
\hline or & 1.8 & 2.1 & 2.8 & 2.7 & 1.1 \\
\hline$a b$ & 53.4 & 43.5 & 45.5 & 48.3 & 24.4 \\
\hline an & 11.2 & 14.2 & 12.8 & 11.1 & 28.3 \\
\hline c & 0.2 & & 0.0 & 0.9 & \\
\hline $\begin{array}{l}\text { wo } \\
\text { en }\end{array}$ & & 1.4 & & & $\begin{array}{l}10.4 \\
14.7\end{array}$ \\
\hline $\begin{array}{l}\text { en } \\
\text { fs }\end{array}$ & 4.1 & 2.1 & 5.8 & 0.9 & $\begin{array}{l}14.7 \\
10.3\end{array}$ \\
\hline $\begin{array}{l}\text { fs } \\
\text { fo }\end{array}$ & 7.2 & 8.5 & 4.1 & 3.3 & $\begin{array}{r}10.3 \\
3.1\end{array}$ \\
\hline fa & & & & & 2.4 \\
\hline $\mathrm{mt}^{\mathrm{b}}$ & 1.0 & 1.0 & 00.5 & 0.4 & 1.6 \\
\hline il & 2.7 & 1.7 & 1.4 & 1.0 & 3.3 \\
\hline ap & & & & & 0.4 \\
\hline
\end{tabular}

${ }^{a}$ Repeated focussion of the electron beam may have evaporated Na. For C.I.P.W. norm calculation, linear relation between $\mathrm{SiO}_{2}$ and $\mathrm{Na}_{2} \mathrm{O}$ contents were assumed for the analyses of 2 through bulk rock.

${ }^{\mathrm{b}} \mathrm{Fe}^{3+} /($ total $\mathrm{Fe}$ ) was supposed to be 0.1 for the norm calculation.

$\mathrm{FeO} * / \mathrm{MgO}$ ratio increases, while composition of the residual melt in the groundmass changes toward Ca-pyroxene apex first, then towards silica apex. The compositional trend of ocean-floor basalt is nearly parallel to the experimentally deduced equilibrium cotectic line of plagioclase, olivine, and Ca-rich clinopyroxene under low pressures (Shibata, 1976), thus suggesting that the compositional trend of ocean-floor basalt is controlled by cotectic crystallization of these phases. Departure of the compositions of the fillings and the interstitial material from the cotectic line indicates the suppression of the crystallization of Ca-rich clinopyroxene during crystallization of pillow lavas. Rapid cooling of pillows may be responsible for the supercooling of $\mathrm{Ca}$-rich clinopyroxene. The supercooling effect is also implied by the overwhelming spherulitic and dendritic textures of $\mathrm{Ca}$-rich clinopyroxene in the groundmass.

Smith (1968) discussed how the once gas-filled vesicles could be infiltrated by the residual silicate melt, and deduced that the infiltration is due to the movement of lava into the deeper part of a shallow sea floor, which increases the 


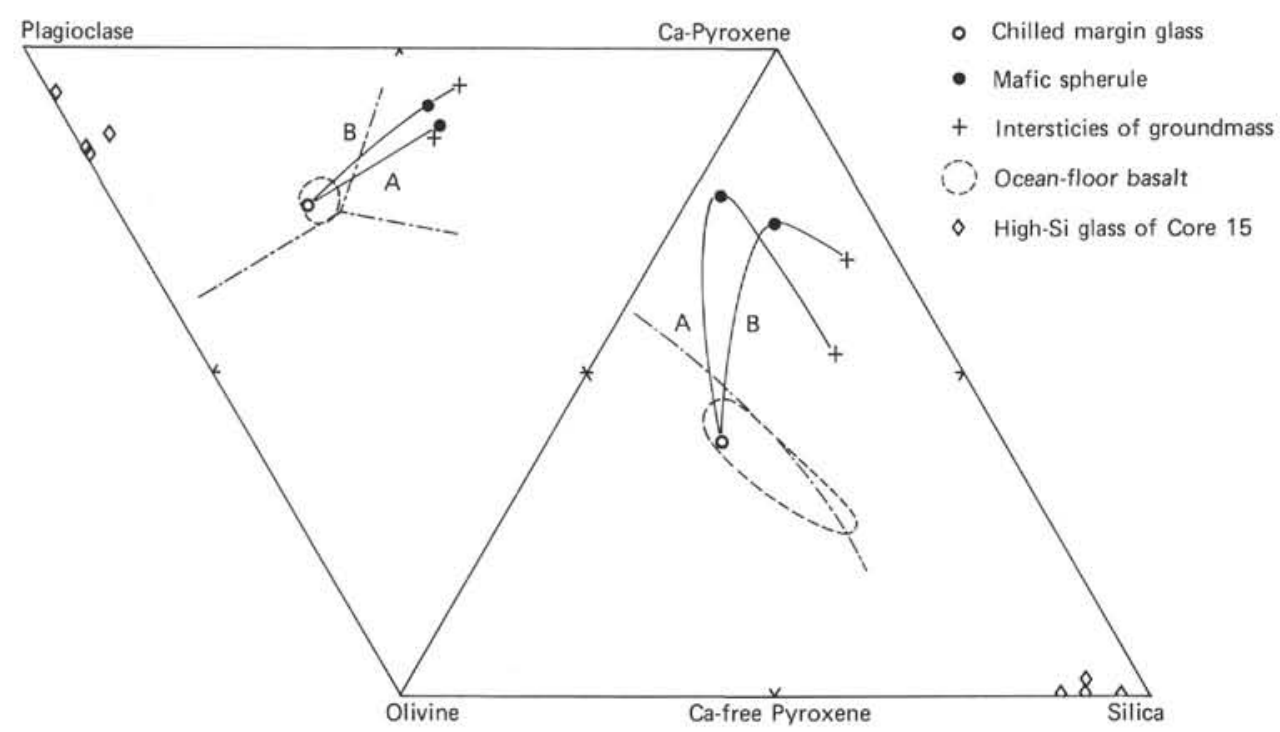

Figure 1. Normative projection (molar basis) of the composition of groundmass materials and the chilled margin glasses of Hole $396 B$ basalts. Solid lines $A$ and $B$ represent compositional trends of outer (sample 4I) and inner (4G) parts of a pillow. Compositional field of Fe-rich ocean-floor basalt is taken from Clague and Bunch (1976). Dot-dash lines represent approximate cotectic boundaries of olivine, plagioclase, and Ca-rich clinopyroxene (Shibata, 1976).

relative load pressure by more than factor of two and lessens the volume capacities of gas vesicles. It is not conceivable that the Leg 46 basalts now at depth of about 4500 meters below sea level were formed at such shallow depth, because the basalts have low vesicle contents, i.e., less than 5 per cent (Moore and Schilling, 1973). Some other mechanism of the infiltration may have been effective.

The presence of the immiscible liquid droplets in the Leg 46 basalts may be related to some extent to the delay of the crystallization of Ca-rich clinopyroxene during crystallization of pillow matrix. The conditions of occurrence of liquid immiscibility are a high concentration of $\mathrm{TiO}_{2}, \mathrm{FeO} *, \mathrm{MgO}$, and $\mathrm{CaO}$, and a depletion of $\mathrm{Al}_{2} \mathrm{O}_{3}$ (Roedder, 1951; Watson, 1976; Hess, 1977). The excess crystallization of plagioclase over suppressed Ca-rich clinopyroxene during crystallization of groundmass may have allowed the liquid composition to reach the liquid immiscibility field. It is not certain if the liquid immiscibility found in Leg 46 basalt is a metastable one, as has been demonstrated by Irvine (1976).

The low-index glass in the mesostasis of the massive lava of Leg 46 (Figure 2) has a composition of plagiogranite of Coleman and Peterman (1975). Petrographic data indicate that the mesostasis represent the residual melt after 95 to 98 per cent of the groundmass has crystallized. The fractionation involves crystallization of olivine, plagioclase, Ca-rich clinopyroxene, titanomagnetite, sulfide, and possibly ilmenite, and the liquid immiscibility of high-index glass droplet depleted in $\mathrm{Si}$ and $\mathrm{Al}$, and enriched in $\mathrm{Ti}, \mathrm{Fe}$, and $\mathrm{Mg}$. (Quantitative analyses of high-index glass was not possible because of the small size, but bulk analyses of mesostasis charged with high-index glass droplets confirm these chemical features.) The fractionation behavior of ocean-floor

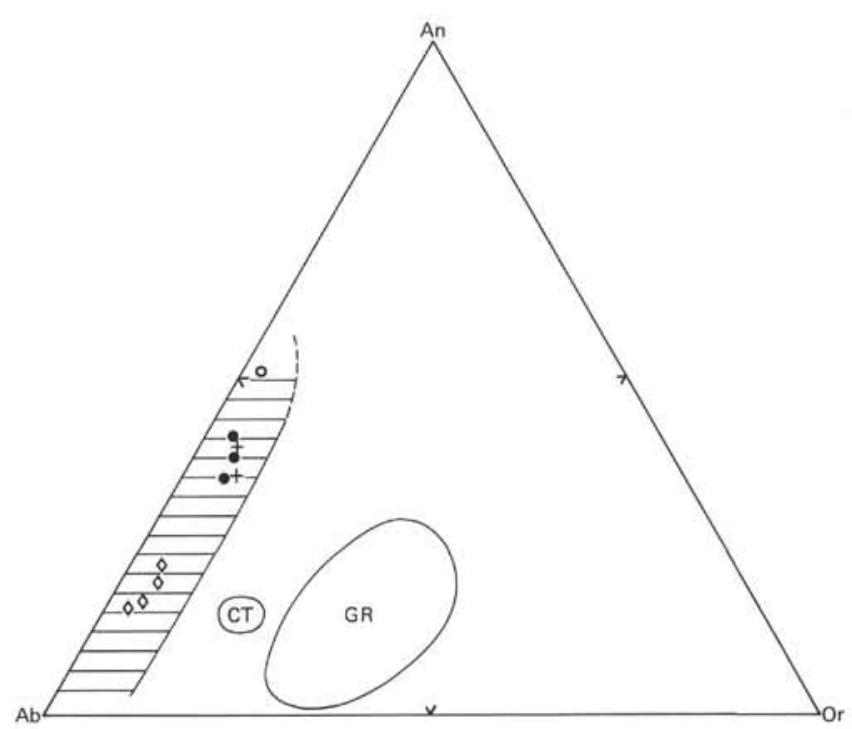

Figure 2. Normative feldspar projection (Molar basis) of the compositions of groundmass materials and the chilled margin glass of Hole $396 \mathrm{~B}$ basalt. Symbols are the same as in Figure 1. The hatched area is the compositional field of plagiogranite, CT; continental trondhjemite, GR; granophyre, taken from Coleman and Peterman (1975).

basalts in the intraterrullic environment may differ from those in the groundmass of the erupted lavas; however, the presence of residual melt of plagiogranite composition in the groundmass of the ocean-floor basalt support the view of Coleman and Peterman that plagiogranite is derived from ocean-floor basalts. 


\section{CONCLUSIONS}

1. Segregation vesicles are common in the microcrystalline and intersertal parts of pillow and massive lavas of Hole 396B, IPOD/DSDP Leg 46. Infiltrated material in the segregation vesicles has high $\mathrm{FeO} * / \mathrm{MgO}$ ratios, and represents residual melt after 40 to 60 per cent of the crystallization of groundmass.

2. The chemical composition of the infiltrated material differs from that of $\mathrm{Fe}$-rich ocean-floor basalts by higher $\mathrm{CaO}$ and lower $\mathrm{Al}_{2} \mathrm{O}_{3}$ content. The supercooling of $\mathrm{Ca}$-rich clinopyroxene is considered responsible for the enrichment of the normative Ca-pyroxene content in the residual liquid during the crystallization of groundmass.

3. Dark, minute, high-index glass droplets set in a low-index glass are found in the mesostasis of the most coarse-grained parts of pillow and massive lavas of Hole 396B. These glasses may represent immiscibility in the fractionated residual melt in the groundmass.

4. The low-index glass in the mesostasis of the massive lava has the composition of trondhjemite or plagiogranite and represents the last few per cent of the residue during fractional crystallization of the groundmass.

\section{ACKNOWLEDGMENTS}

Dr. S. Banno of Kanazawa University and Dr. J. Kirkpatrick of DSDP kindly read the manuscript and gave valuable suggestions. Dr. N. Isshiki of the Geological Survey of Japan informed the author about literature on the segregation vesicles.

\section{REFERENCES}

Baragar, W.R.A., Plant, A.G., Pringle, G.J., and Schau, M., 1977. Petrology and alteration of selected units of Mid-Atlantic Ridge basalts sampled from Sites 332 and 335, DSDP. Canadian J. Earth Sci., v. 14, p. 837-874.

Clague, D.A., and Bunch, T.E., 1976. Formation of ferrobasalt at East Pacific Midocean Spreading Centers, J. Geophys. Res., v. 81, p. $4247-4256$.
Coleman, R.G, and Peterman, Z.E., 1975. Oceanic plagiogranite, J. Geophys. Res., v. 80, p. 1099-1108.

De, A., 1974. Silicate liquid immiscibility in the Deccan traps and its petrogenetic significance, Geol. Soc. Am. Bull., v. 85, p. 471-474.

Hess, P., 1977. Structure of silicate melts, Canadian Mineralogist, v. 15, p. 162-178.

Irvine, T.N., 1977. Metastable liquid immiscibility and MgO$\mathrm{FeO}-\mathrm{SiO}_{2}$ fractionation patterns in the system $\mathrm{Mg}_{2} \mathrm{SiO}_{4}$ $\mathrm{Fe}_{2} \mathrm{SiO}_{4}-\mathrm{CaAl}_{2} \mathrm{Si}_{2} \mathrm{O}_{8}-\mathrm{KAlSi}_{3} \mathrm{O}_{8}-\mathrm{SiO}_{2}$, Carnegie Institution of Washington, Year Book, v. 76, p. 597-611.

Massion, P.J., and Koster van Groos, A.F., 1973. Liquid immiscibility in silicates, Nature, Physical Science, v. 245, p. 60-63.

Miyashiro, A., Shido, F., and Ewing, M., 1969. Diversity and origin of abyssal tholeiite from the Mid-Atlantic Ridge near $24^{\circ}$ and $30^{\circ}$ north latitude, Contrib. Mineral. Petrol., v. 23, p. $38-52$.

Moore, J.G., and Schilling, J.G., 1973. Vesicles, water and sulfur in Reykjanes Ridge basalts, Contrib. Mineral. Petrol., v. 41, p. 105-118.

Roedder, E., 1951. Low temperature liquid immiscibility in the system $\mathrm{K}_{2} \mathrm{O}-\mathrm{FeO}-\mathrm{Al}_{2} \mathrm{O}_{3}-\mathrm{SiO}_{2}$, Am. Mineralogist, v. 36, p. $282-286$.

Roedder, E., and Weiblen, P.W., 1970. Silicate liquid immiscibility in lunar magmas, evidenced by melt inclusions in lunar rocks, Science, v. 167, p. 641-644.

, 1971. Petrology of silicate melt inclusions, Apollo 11 and Apollo 12 and terrestrial equivalents, Second Lunar Sci. Conf. Proc., v. 1, p. 507-528.

1972. Petrographic features and petrologic significance of melt inclusions in Apollo 14 and 15 rocks, Third Lunar Sci. Conf. Proc., v. 1, p. 251-279.

Shibata, T., 1976. Phenocryst-bulk rock composition relations of abyssal tholeiites and their petrogenetic significance, Geochim. Cosmochim. Acta, v. 40, p. 1407-1417.

Smith, R.E., 1968. Segregation vesicles in basaltic lava, Am. J. Sci., v. 265, p. 696-713.

Watson, E.B., 1976. Two-liquid partition coefficients: experimental data and geochemical implications, Contrib. Mineral. Petrol., v. 56, p. 119-134. 

PLATE 1

Segregation Vesicles and Intersertal Matrix

(Bars are $0.2 \mathrm{~mm}$.)

Figure 1 Segregation vesicle in the intersertal groundmass of Sample 396B-20-1, 89-91 cm.

Figure 2 Partly filled segregation vesicle in the microcrystalline spherulitic groundmass of Sample 396B-13-2, 39-40 cm.

Figure 3 Almost completely filled segregation vesicle in the microcrystalline spherulitic groundmass of Sample 396B-16-1, 75-77 cm.

Figure 4 Part of a segregation vesicle in Sample 396B-20-1, 93-95 cm.

Figure 5 The same as Figure 4, reflected light. Note the dendritic Ca-rich clinopyroxene.

Figure 6 Intersertal matrix in Sample 396B-32-1, 78-81 cm. 
PLATE 1
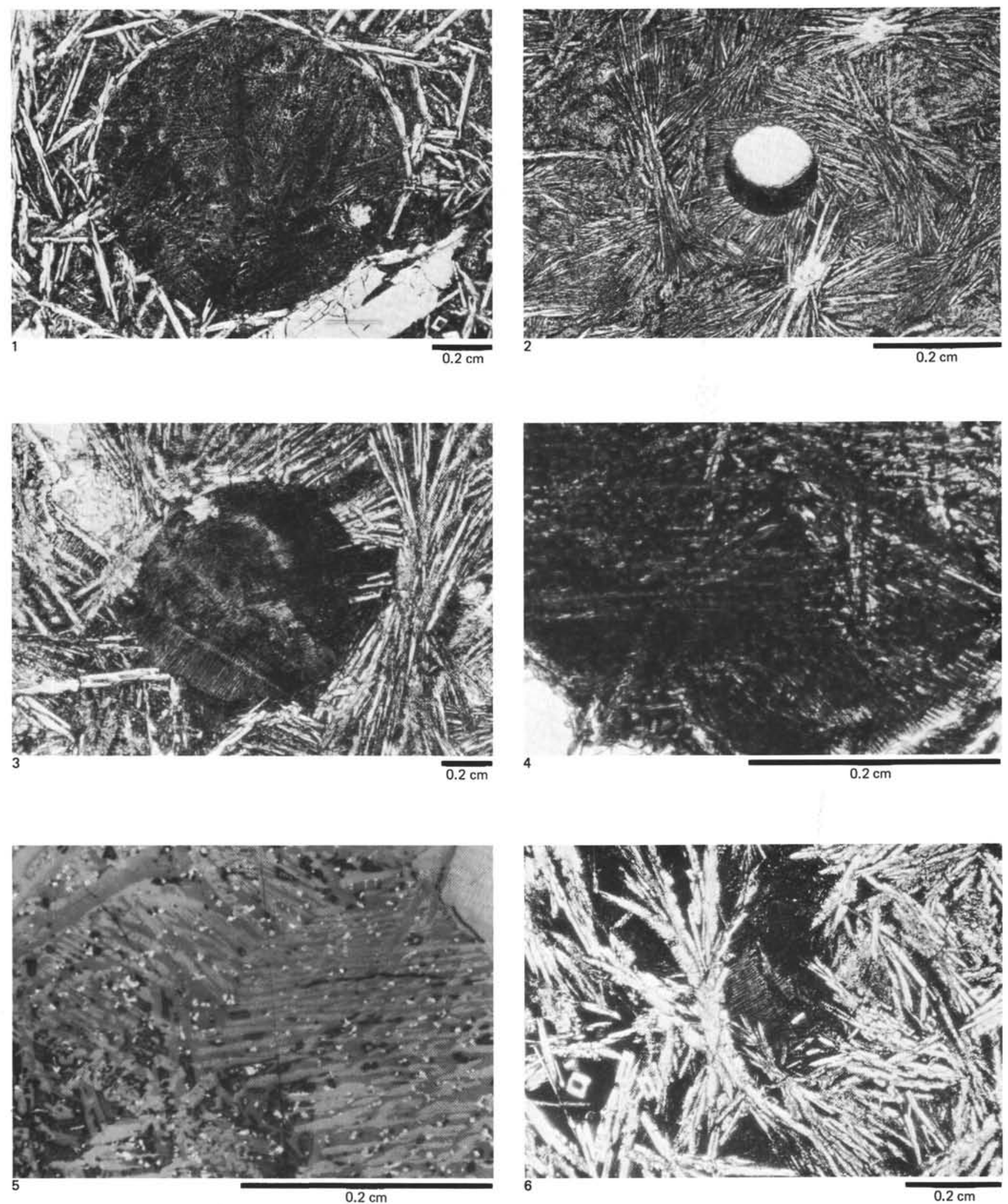
PLATE 2

Liquid Immiscible Droplet and Mesostasis Glass

(Bars are $10 \mu \mathrm{m}$ for Figures 1, 2, and 3; and $100 \mu \mathrm{m}$ for Figure 4.)

Figure 1

Figure 2

Figure 3

Figure 4
Liquid immiscible droplets in Sample 396B-15-4, $65-80 \mathrm{~cm}$.

The same as Figure 1.

Liquid immiscible droplets in Sample 396B-14-3, $56-62 \mathrm{~cm}$.

Mesostasis glass in Sample 396B-15-4, 45-55 cm. 
PLATE 2
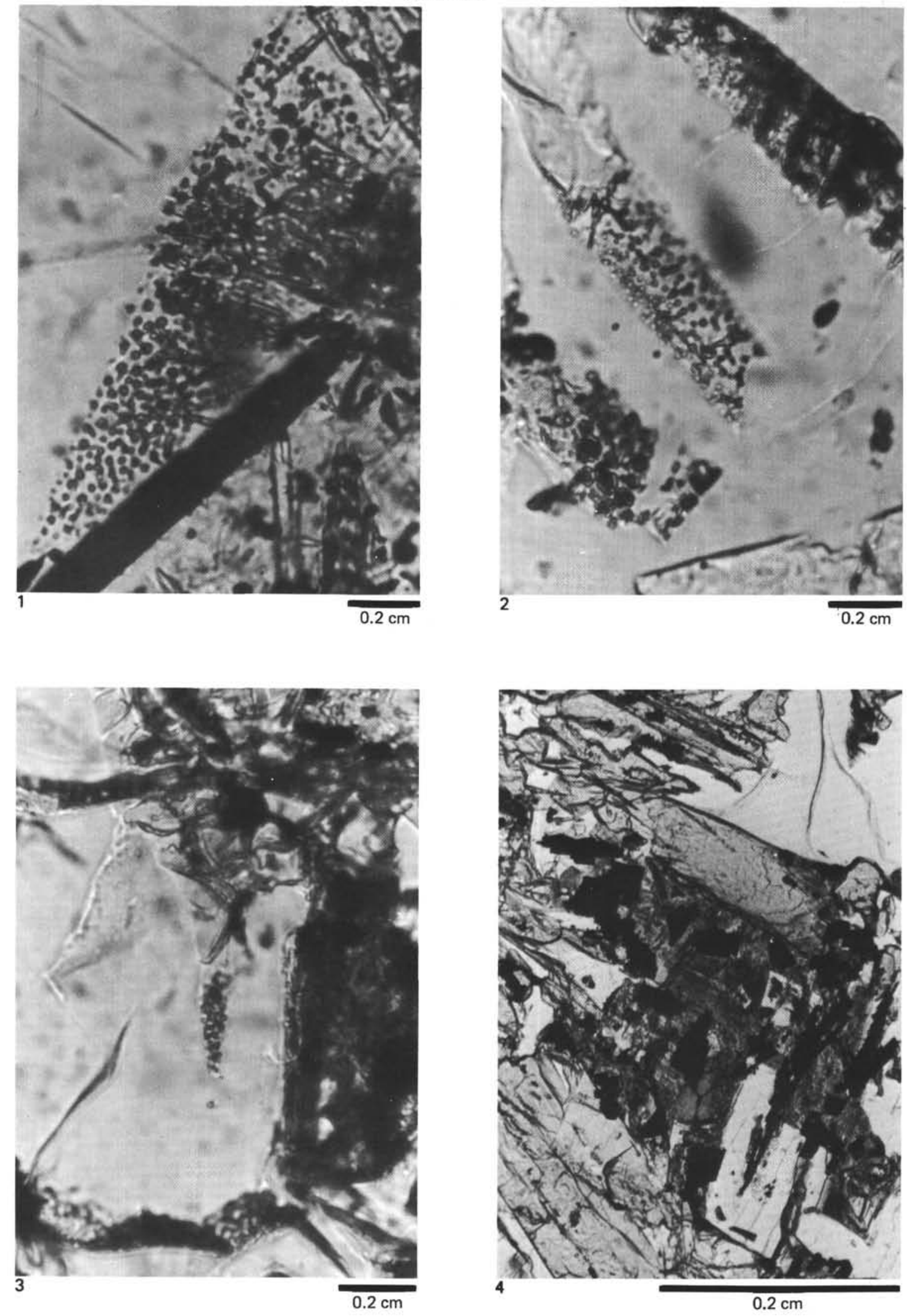